\title{
Personalized Medicine: A Review with Regard to Biomarkers
}

\section{Behzad Foroutan*}

Department of Pharmacology, School of Medicine, Shahroud University of Medical Sciences, Shahroud, Iran

\begin{abstract}
Personalized medicine (PM) is an emerging practice of medicine that uses an individual's genetic profile to guide decisions made in regard to the diagnosis, prevention and treatment of diseases. Personalized medicine is being advanced through data from the Human Genome Project. It is beginning to achieve its goal of "the right therapy to the right patient at the right time". Today PM is moving us closer to more precise, predictable and powerful medication customized for an individual patient. By the way the genomic data is the driving force behind PM. Upward understanding of genetics is allowing us to provide better diagnoses, safer medication prescribing, and more effective therapy of the diseases and conditions that have affected us throughout history. Therapies targeting biomarkers have been associated with several successes in the last decades, together with their limits and related unsolved questions. Most of tumors will eventually develop resistance potentially due to intra-tumor heterogeneity and selection of additional molecular events. Furthermore, studies in the field of molecular characterization of tumors have shown that most tumors comprise large number of rare genomic events. Administering one single medication will incur in non-durable results. So the future is to smartly develop personalized therapies which could change the regular history of several diseases mainly tumors. Notably PM will not change traditional therapy however, in regards to biomarkers; it might create a safe and effective therapy for every individual patient. Knowledge of a patient's genetic profile can help physicians select the proper medication or therapy and administer it using the proper dose or regimen. Opportunities and challenges for PM would also be discussed in this review.
\end{abstract}

Personalized medicine will create significance value for the healthcare system but there is a quite a bite of debate over where the value will accrue.

Keywords: Personalized medicine; Biomarkers

\section{Introduction}

In $21^{\text {st }}$ century, the world has faced substantial and remarkable progressions in biology [1], pharmacy, genetics [2] and medicine [3-6]. The twenty-first century medicine is becoming progressively proactive and has been described as "predictive, personalized, preventive and participatory (P4) medicine [7].

Traditionally, physicians use family history, socioeconomic circumstances, and environmental factors to cure their patients. Nowadays cure approaches and managements do more depend on genomic/genetic testing, proteomic profiling [8] and metabolomics [9]. The metabolome represents the collection of all metabolites in a biological cell, tissue, organ or organism, which are the end products of cellular processes [10]. These considerations justify the development of molecular medicine with the characterization of each tumor to assess defects in all systems to propose a unique combination of therapies to each patient. Current medication development is clearly not appropriate [11], and studies with medications given in relevant combinations should be favored by new relationships between clinical needs and industry.

High throughput sequencing of major tumors has provided an enhanced understanding of molecular mechanisms that generate tumor transformation and progression [12]. The so-called oncogenic drivers will allow initial steps of the oncogenesis [13]. Oncogenic drivers are usually generated by genomic alterations, like ERBB2 amplification [14], EGFR and B-Raf mutations [15]. Targeting these oncogenic drivers is called "oncogene de-addiction" and is expected to result in tumor shrinkage [16]. In addition progressions will be involved in chemoresistance, radioresistance and metastatic dissemination. As an illustration, EGFR T790M and ESR1 mutations mediate resistance to the epidermal growth factor receptor inhibitors and endocrine therapy respectively.
The p53 the master tumor repressor that participates in vast regulatory networks, in addition to playing roles in the genesis and progression of tumor, mutant p53 also appears to play a significant role in the response to cancer therapy $[17,18]$. A major challenge in molecular medicine will be to target these alterations early enough, in order to avoid treatment resistance. Whether these genomic alterations are present as a "minority subclone" in the initial tumor or are acquired during tumor progression is still an open question. Furthermore distinct phenotypic and mutational profiles that can occur within different localizations in the same tumor (intra-tumor heterogeneity) and genomic instability (the elevated rate of spontaneous molecular alterations occurring in tumors) are involved in the Darwinian selection of minority clones and potentially responsible for the development of resistance to oncogene de-addiction.

Pharmacy has been part of a revolution in health care that has led to increases in average life span, the percentage of healthy elderly in the population, and decreased impact of chronic diseases [19-26]. The role of medications and their proper use has improved throughout these advances [27].

Dramatic advances in information technology are driving systems change. The United States (US) and other countries are currently making multibillion-dollar investments to implement Electronic health records

*Corresponding author: Behzad Foroutan, Department of Pharmacology, School of Medicine, Shahroud University of Medical Sciences, Shahroud, 3614773955, Iran, Tel: 00982332395054; Fax: 00982332394800; E-mail: behzad_foroutan@hotmail.com

Received July 08, 2015; Accepted August 10, 2015; Published August 17, 2015

Citation: Foroutan B (2015) Personalized Medicine: A Review with Regard to Biomarkers. J Bioequiv Availab 7: 244-256. doi:10.4172/jbb.1000248

Copyright: (c) 2015 Foroutan B. This is an open-access article distributed under the terms of the Creative Commons Attribution License, which permits unrestricted use, distribution, and reproduction in any medium, provided the original author and source are credited. 
(EHRs) to improve clinical care. The development of such records creates several new opportunities to integrate health-care information and biological data and to search for new links between clinical test results, patient data, and outcomes. Several health-care systems in the US have started accumulating large EHR databases linked to clinical bio-samples. Notable among the US efforts are the Harvard University/ Partners Healthcare i2b2 effort, the Vanderbilt BioVu effort [28], the UCSF-Kaiser collaboration and the multi-center eMERGE Network [29]. Early studies have shown that gene expression arrays and next generation sequencing could be performed on the vast majority of patient samples, with a robust assessment of the genomic profile [3032]. Overall the unique and 'personal' history of each tumor has now been markedly revealed by technological developments that are now been evaluated as tools to guide treatment decision in PM initiatives.

This review aims to highlight the recent individual approaches about $\mathrm{PM}$ and builds a construction between precise individual treatment and distinct biomarkers. The review would also endeavor to go through this concept that which of these biomarkers are the main pillars of PM to cure diseases for each individual patient. To clarify lagging behind, some of the issues and challenges facing new treatments in the current development climate when the request for diagnostics detecting genomic, proteomic, or gene expression biomarkers to accompany new therapies is growing the understanding of how best to achieve this growth would be the other aim of this review. Although kinase activation has dominated the field of PM [33], numerous new areas of tumor biology including DNA repair [34] and metabolism [35] are having an increasing impact in the field. Finally targeting immune suppression networks could be a leading way to control tumor progression [36], and that mechanisms of immune suppression are individual. The scope of this review will not include patient's stratification for prognosis, or prediction of toxicities but will instead focus on promising genomic tests that show potential to improve outcome in the metastatic setting in the contemporary medicine.

Personalized medicine seeks to improve tailoring and timing of preventive and therapeutic measures by utilizing biological information and biomarkers on genetics, proteomics as well as metabolomics and the level of molecular disease pathways [37]. It is a new capable innovation and starts with the patient in practice, rather than, having a unique treatment. Personalized medicine is aiming and endeavoring to sub-divided patients into different categories based on their "molecular make up", i.e. using biomarkers. This type of categorizing enables us to make a decision to have a unique and precise treatment for each patient. Prominently researchers have observed inter individual differences in clinical traits and therapy responses for centuries. Historical examples include the four humors theory used by Hippocrates to diagnose and to prescribe therapy for individual patients; AL Fox's observation of inter-individual variability in phenylthiocarbamide taste perception; R Bonicke's, W Reif's, and HB Hughes's description of inter-patient differences in unchanged Isoniazid urinary excretion that was later found to be due to differences in metabolic acetylation activity; and the increased episodes of Primaquine induced acute hemolytic crises witnessed in African American soldiers compared to Caucasians during World War II [38].

Through this categorizing medical interventions could be tailored to be more effective in a particular group of patients. Personalized medicine most frequently refers to a "medical model" using biomarker profiling for tailoring the right therapeutic strategy for the right patient at the right time, and/or to determine the predisposition to disease and/or to deliver timely and stratified prevention. Personalization is a medical model in which medical care is customized to individual patients [39]. It may also involve imaging and other technologies and will create both opportunities and challenges for traditional healthcare in the today's superb modern science and technology. As patients are divided into groups based on their individual, biological, genetic and genomic characteristics, medical interventions are tailored to those patients' needs. This rapidly developing science-driven approach to health care has potentially too many benefits for patients, clinicians and health care systems alike. Advantages may include the ability to make more informed medical decisions; a higher probability of desired outcomes thanks to better-targeted therapies; a reduced probability of adverse reactions to medications; a focus on prevention and prediction of disease rather than reaction to it; earlier disease intervention than has been possible in the past; and improved healthcare cost-containment.

It takes into account individual genetic differences to use specific characteristics from a patient's genotype to: a) initiate a preventative measure against the development of a disease or condition, or b) select the most appropriate therapy for a disease or condition that is particularly well-matched to that patient.

Genetic variation contributes to both treatment response and disease susceptibility. Traditionally, health providers used family history, socioeconomic circumstances and environmental factors. Today genomic/genetic testing, proteomic profiling study of medications metabolites present themselves very effectively. Human Genome Project in 2003 [40] Phase I HapMap project in 2005 [41], encyclopedia of DNA Elements in 2004 [42] and identification and analysis of functional elements in $1 \%$ of the human genome by the ENCODE pilot project in 2007 [43] made a significant difference. In addition 1000 Genomes Project in 2008 [44,45], and DNA sequences, a plan to capture human diversity in 1000 genomes [46] raised up the knowledge of the human genome. Therefore medications that target the genetic signatures of diseases are making inroads into the superb modern science and technology era.

Today with understanding advanced therapies such as chemo, radio and immunotherapy and patients' biomarkers profiles which are constructed on their genetics map PM defies to identify the genetic drivers of individual diseases, cure and failure of medications for each individual patient. This new horizon would able and guide the researchers to produce next wave of innovation in targeted therapies of diseases specially tumors. Finally this approach will entail sciencedriven combination therapies within and across biomarkers functions and pathways to develop new medications for biomarker-selected patient populations, with the aim to considerably improve patient outcomes.

\section{Biomarkers}

A biomarker, or biological marker, generally refers to a measurable indicator of some biological state or condition (Table 1). Biomarkers include genes, protein, genetic variations and differences in metabolic expression from different sources such as body fluids and tissues.

\section{Most important tumor biomarkers}

Perhaps urinary Bence Jones protein and tumor specific antigen carcinoembryonic antigen in colon carcinomas are the earliest examples of tumor biomarkers [59]. Lander's group used genomic signatures as a biomarker for the classification of tumors [60]. The prostate specific antigen (PSA) has been the most important early use of human tumor biomarkers in a clinical setting [61-63] and is still used in clinics today [64]. The most important tumor biomarkers are summarized here. 
Breast: ER/PR and HER-2/neu; Colorectal: EGFR, KRAS and UGT1A1; Gastric: HER-2/neu, GIST, and c-KIT; Head and Neck: p53 and LOH /microsatellite instability; Leukemia/Lymphoma: CD20 Antigen, CD30, FIP1L1-PDGRFalpha, PDGFR, Philadelphia Chromosome (BCR/ABL), PML/RAR alpha, TPMT and UGT1A1; Liver: AFP, AFLP and DCP; Lung: ALK, EGFR and KRAS; Melanoma: BRAF; Uterine and Cervical: HPV infection and oncogene E6 and E7 expression (Tables 2 and 3 ).
It is necessary to distinguish between prognostic and predictive biomarkers for PM. Following Buyse et al. [131], the difference is that prognostic biomarkers help in predicting the progress of the disease, while predictive biomarkers are connected with the response to a treatment.

\section{Molecular make-up of the human genome}

When scientists first sequenced the human genome; they succeeded

\begin{tabular}{|c|c|}
\hline Term & Description \\
\hline Biomarker & $\begin{array}{l}\text { A characteristic that is objectively measured and evaluated as an indicator of normal biological processes, pathogenic processes, } \\
\text { or pharmacologic responses to a therapeutic intervention [48]. }\end{array}$ \\
\hline Cancer biomarker & $\begin{array}{l}\text { A biomarker that is present in tumor tissue or serum and includes many different molecules, such as DNA, mRNA. Cancer } \\
\text { biomarkers are measured in cancer tissue, and cancer DNA biomarkers are measured from cancer tissue. }\end{array}$ \\
\hline Clinical endpoint & $\begin{array}{l}\text { A characteristic or variable that reflects how a patient feels, functions, or survives [48]. Clinical endpoints can be obtained from } \\
\text { different modalities, such as, behavioral or cognitive scores, or biomarkers from Electroencephalography (qEEG), MRI, PET, or } \\
\text { biochemical biomarkers }\end{array}$ \\
\hline Companion endpoint & A biomarker that is essential to the efficacy and safety of a corresponding therapeutic product [49]. \\
\hline Copy number variant (CNV) biomarker & A biomarker of genomic variation in which blocks of DNA are missing or for which multiple copies exist [50]. \\
\hline Diagnostic biomarker & $\begin{array}{l}\text { A biomarker that relates to the diagnosis or severity of disease. The most important diagnostic biomarkers are screening } \\
\text { biomarkers [51]. }\end{array}$ \\
\hline Disease biomarker & A biomarker that relates to a clinical endpoint or measure of disease [52]. \\
\hline DNA biomarker & A germline biomarker, such as SNPs, STRs, insertions, deletions, or other variation on the DNA sequence level [47]. \\
\hline Efficacy biomarker & A biomarker that predicts a beneficial effect of a given treatment [52]. \\
\hline Epigenetic biomarker & $\begin{array}{l}\text { A biomarker that measures epigenetic alterations, such as DNA methylation, histone methylation, histone acetylation, microRNAs, } \\
\text { or other non-coding RNA [53]. }\end{array}$ \\
\hline Monitoring biomarker & A biomarker to monitor efficacy or side effects of a medication treatment [54]. \\
\hline *Prognostic biomarker & A biomarker that predicts the likely course of disease in a defined clinical population under standard treatment conditions [55]. \\
\hline Prediction model & A predictive test including multiple markers [56]. \\
\hline${ }^{*}$ Predictive biomarker & $\begin{array}{l}\text { A biomarker that forecasts the likely response to treatment [49]. Treatment response may be measured either as efficacy or as } \\
\text { safety. }\end{array}$ \\
\hline Predictive test & $\begin{array}{l}\text { Two definitions exist in the literature a test of test of probability for an individual to develop a disease; alternatively, a test which } \\
\text { discriminates between individuals who will develop a disease and those who will not [57]. }\end{array}$ \\
\hline Risk prediction & $\begin{array}{l}\text { The generation or validation of models which make a prognosis for developing a disease or the prognosis for attaining a clinical } \\
\text { endpoint. }\end{array}$ \\
\hline Safety biomarker & A biomarker that indicates adverse response to a treatment [58] Toxicity biomarkers are special cases of safety biomarkers. \\
\hline Screening biomarker & $\begin{array}{l}\text { A biomarker to discriminate between healthy individuals and those in an early stage of the disease [52] ideally while subjects are } \\
\text { asymptomatic. }\end{array}$ \\
\hline Staging biomarker & A biomarker that distinguishes between different stages of chronic disease [52]. \\
\hline Stratification biomarker & See predictive biomarker. \\
\hline Surrogate biomarker & $\begin{array}{l}\text { A biomarker that is regarded as a valid substitute for a clinical endpoint. A surrogate endpoint is expected to predict clinical benefit } \\
\text { (or harm or lack of benefit or harm) (Biomarkers Definitions Working Group [48,52]. }\end{array}$ \\
\hline Target biomarker & A biomarker that reports interaction of the medication with its target [52]. \\
\hline Toxicity biomarker & A biomarker that reports to the toxic effect of a medication on an in vitro or in vivo system [52]. \\
\hline
\end{tabular}

Table 1: Important terms in biomarker studies, taken and modified from Ref [47].

\begin{tabular}{|c|c|c|c|c|c|}
\hline Type of Tumor & $\begin{array}{l}\text { *Prognostic } \\
\text { Biomarker }\end{array}$ & Clinical Significance & Detection & $\begin{array}{l}\text { Clinical } \\
\text { Use }\end{array}$ & Ref. \\
\hline Bladder & CD44 & Expression of CD44 is associated with poor prognosis & qRT-PCR & No & [65] \\
\hline Bladder & Cyclin D1 & Expression of Cyclin D1 is associated with low grade, low stage and recurrence & $\mathrm{IHC}$ & No & [66] \\
\hline Bladder & Cyclin E & Expression of Cyclin E is associated with low stage and survival & $\mathrm{IHC}$ & No & [67] \\
\hline Bladder & E-Cadherin & E-Cadherin is associated with poor prognosis & $\mathrm{IHC}$ & No & [68] \\
\hline Bladder & EGFR & Overexpression of EGFR is associated with high grade and high stage & $\mathrm{IHC}$ & No & [69] \\
\hline Bladder & & $\begin{array}{l}\text { Overexpression of Her } 2 / \text { neu is associated with high grade, high stage, poor survival and } \\
\text { metastasis in bladder cancer }\end{array}$ & $\mathrm{IHC}$ & No & [70] \\
\hline Bladder & Ki-67 & Expression of $\mathrm{Ki}-67$ is associated with progression and recurrence in bladder cancer & $\mathrm{IHC}$ & No & [71] \\
\hline Bladder & MMP-2 & Expression of MMP-2 is associated with poor prognosis in bladder cancer patients & PCR & No & [72] \\
\hline Bladder & $\mathrm{Rb}$ & Overexpression of $\mathrm{Rb}$ is associated with poor prognosis & $\mathrm{IHC}$ & No & [73] \\
\hline Bladder & p21 & Overexpression of p21 is associated with poor prognosis & $\mathrm{IHC}$ & No & [74] \\
\hline Bladder & p53 & Overexpression of p53 is associated with poor prognosis & $\mathrm{IHC}$ & No & [75] \\
\hline Breast & & Expression of $\mathrm{Ki}-67$ is associated with proliferation and progression in breast cancer & $\mathrm{IHC}$ & No & [76] \\
\hline
\end{tabular}




\begin{tabular}{|c|c|c|c|c|c|}
\hline Breast & BRCA1 & High expression of BRCA1 confers worse prognosis in untreated patients & IHC & Yes & [77] \\
\hline Breast & & $\begin{array}{l}\text { Breast cancer patients with } \geq 5 \mathrm{CTC} / 7.5 \mathrm{ml} \text { of peripheral blood are associated with } \\
\text { shorter PFS and OS, i.e. poor prognosis }\end{array}$ & Circulating tumor cells & Yes & [78] \\
\hline Breast & ER & $\begin{array}{l}\text { Patients with ER-positive breast tumors have better survival than patients with hormonal } \\
\text { negative tumors }\end{array}$ & $\mathrm{IHC}$ & Yes & [79] \\
\hline Breast & eXagene $B C$ & Provides prognosis in node-positive or node-negative breast cancer patients & FISH & Yes & [80] \\
\hline Breast & Her2/neu & $\begin{array}{l}\text { Patients with Her2/neu-positive breast tumors are more aggressive and have a worse } \\
\text { prognosis compared to Her2/neu-negative tumors }\end{array}$ & FISH & Yes & [81] \\
\hline Breast & MammaPrint & $\begin{array}{l}\text { A 70-gene prognostic assay used to identify breast cancer cases at the extreme end } \\
\text { of the spectrum of disease outcome by identifying patients with good or very poor } \\
\text { prognosis }\end{array}$ & Microarray & Yes & [82] \\
\hline Breast & Mammostrat $\AA$ & $\begin{array}{l}\text { This standard purely prognostic test uses five antibodies with manual slide scoring to } \\
\text { divide cases of ER-positive, lymph node negative breast cancer tumors treated with } \\
\text { tamoxifen alone into low-, moderate- or high-risk groups }\end{array}$ & $\mathrm{IHC}$ & Yes & [83] \\
\hline Breast & Oncotype DX & $\begin{array}{l}\text { A 21-gene multiplex test used for prognosis to determine } 10 \text {-year disease recurrence for } \\
\text { ER-positive, lymph node negative breast cancers using a continuous variable algorithm } \\
\text { and assigning a tripartite recurrence score }\end{array}$ & qRT-PCR & Yes & {$[84,85]$} \\
\hline Breast & PR & $\begin{array}{l}\text { Patients with PR-positive breast tumors have better survival than patients with } \\
\text { hormonal-negative tumors }\end{array}$ & IHC & Yes & [86] \\
\hline CRC & & $\begin{array}{l}\text { Colorectal patients with } \geq 3 \mathrm{CTC} / 7.5 \mathrm{ml} \text { of peripheral blood were associated with shorter } \\
\text { PFS and OS, i.e. poor prognosis }\end{array}$ & Circulating tumor cells & Yes & [87] \\
\hline CRC & CEA & $\begin{array}{l}\text { Elevated preoperative CEA levels in resectable colorectal cancer is associated with } \\
\text { poor prognosis }\end{array}$ & IHC & Yes & {$[88,89]$} \\
\hline CRC & ColoPrint & Prognosis for colorectal cancer patients & Microarray & Yes & [90] \\
\hline CRC & $\mathrm{LOH}$ at $18 \mathrm{q}$ & Associated with metastasis and poor prognosis in colorectal tumors & PCR & No & [91] \\
\hline CRC & MSI status & $\begin{array}{l}\text { High frequency MSI colorectal tumors are associated with better prognosis and show } \\
\text { improved relapse-free survival }\end{array}$ & IHC & No & [92] \\
\hline GIST & $\mathrm{c}-\mathrm{KIT}$ & $\begin{array}{l}\text { GIST patients have a better prognosis if they harbor a mutation in exon } 11 \text { of the c-KIT } \\
\text { gene }\end{array}$ & $\begin{array}{l}\text { Pathway detection via FDG- } \\
\text { PET }\end{array}$ & Yes & [93] \\
\hline GIST & & $\begin{array}{l}\text { Overexpression of Her } 2 / \text { neu in advanced gastric cancer patients is associated with poor } \\
\text { prognosis }\end{array}$ & IHC & No & [94] \\
\hline Melanoma & $\begin{array}{l}\text { CTC (e.g. } \\
\text { CellSearch) }\end{array}$ & Increased number of circulating melanoma cells is associated with poor prognosis & Circulating tumor cells & No & [95] \\
\hline Melanoma & Her3 & $\begin{array}{l}\text { Correlation with increased cell proliferation, tumor progression and reduced survival in } \\
\text { melanoma patients }\end{array}$ & IHC & No & [96] \\
\hline Melanoma & ING3 & $\begin{array}{l}\text { Reduced nuclear expression associated with poor disease-specific survival in } \\
\text { melanoma patients }\end{array}$ & IHC & No & [97] \\
\hline Melanoma & ING4 & $\begin{array}{l}\text { Reduced levels of ING4 in melanoma patients is associated with melanoma thickness, } \\
\text { ulceration and poor disease-specific survival and overall survival }\end{array}$ & IHC & No & [98] \\
\hline Melanoma & NCOA3 & $\begin{array}{l}\text { Increased levels in melanoma patients correspond to poor relapse-free survival and } \\
\text { disease-free survival }\end{array}$ & IHC & No & [99] \\
\hline NSCLC & Beta-tubulin & High expression of beta-tubulin confers worse prognosis & IHC & No & {$[100,101]$} \\
\hline NSCLC & & High expression of BRCA1 confers worse prognosis in untreated patients & qRT-PCR & No & [102] \\
\hline NSCLC & & High gene copy number of EGFR in NSCLC patients is associated with poor prognosis & $\mathrm{FISH} / \mathrm{SA}$ & No & [103] \\
\hline NSCLC & K-ras & K-ras mutation is associated with poor prognosis in NSCLC patients & SA & Yes & [104] \\
\hline NSCLC & & $\begin{array}{l}\text { High expression of p53 in NSCLC patients confers worse prognosis in untreated } \\
\text { patients }\end{array}$ & IHC & No & [105] \\
\hline NSCLC & & TP53 mutation in NSCLC patients is associated with worse prognosis & SA & No & \\
\hline NSCLC & RRMI & $\begin{array}{l}\text { High expression of RRMI in NSCLC patients confers better prognosis in untreated } \\
\text { patients }\end{array}$ & AQUA & No & [106] \\
\hline Pancreatic & CA19-9 & $\begin{array}{l}\text { Higher preoperative CA19-9 levels are associated with lower resectability, more } \\
\text { advanced stage and inferior survival }\end{array}$ & IHC & No & [107] \\
\hline Prostate & & $\geq 5 \mathrm{CTC} / 7.5 \mathrm{ml}$ of peripheral blood is associated with poor prognosis & Circulating tumor cells & Yes & [78] \\
\hline RCC & CAIX & High expression of CAIX is associated with a better prognosis & IHC & No & [108] \\
\hline $\mathrm{RCC}$ & VEGF & $\begin{array}{l}\text { Overexpression of VEGF is associated with poor prognosis in clear cell renal carcinoma } \\
\text { patients }\end{array}$ & IHC & Yes & [109] \\
\hline Rectal & & Overexpression of EGFR in rectal cancers is also associated with poor prognosis & IHC & No & [110] \\
\hline $\begin{array}{l}\text { Salivary gland } \\
\text { carcinomas }\end{array}$ & EGFR \& C-KIT & $\begin{array}{l}\text { Overexpression EGFR of and absence of C-KIT expression correlate with poor } \\
\text { prognosis in. }\end{array}$ & IHC & & [111] \\
\hline
\end{tabular}

Abbreviations: AQUA: Automated Quantitative Analysis; CA19-9: Carbohydrate Antigen 19-9; CAIX: Carbonic Anhydrase IX; CEA: Carcinoembryonic Antigen; CRC: Colorectal Tumor; CTC: Circulating Tumor Cells; EGFR: Epidermal Growth Factor Receptor; ER: Estrogen Receptor; FDG: 18F-fluorodeoxyglucose; FISH: Fluorescent in situ Hybridization; GIST: Gastrointestinal Stromal Tumor; IHC: Immunohistochemistry; LOH: Loss Of Heterozygosity; MMP-2: Matrix Metalloproteinase-2; MSI: Microsatellite Instability; NSCLC: Non-Small Cell Lung Cancer; OS: Overall Survival; PET: Positron Emission Tomography; PFS: Progression-Free Survival; PR: Progesterone Receptor; qRT-PCR: Quantitative Real Time Polymerase Chain Reaction; Rb: Retinoblastoma; RCC: Renal Cell Carcinoma; RRMI: Ribonucleotide Reductase Messenger 1; SA: Sequence Analysis; VEGF: Vascular Endothelial Growth Factor.

Table 2: "Prognostic biomarkers for tumor medicine, taken and modified from Ref. [55]. 


\begin{tabular}{|c|c|c|c|c|c|}
\hline Type of Tumor & Predictive Biomarker & Clinical Significance & Detection & Clinical Use & Ref. \\
\hline Breast & & High expression of BRCA1 in breast cancer can predict response to chemotherapy & $\mathrm{IHC}$ & Yes & [77] \\
\hline Breast & ER & High cellular expression of ER predicts benefit from tamoxifen-based chemotherapy & IHC & Yes & {$[79,112]$} \\
\hline Breast & Her2/neu & $\begin{array}{l}\text { Breast cancer patients with Her2/neu overexpressing tumors benefit from treatment } \\
\text { with trastuzumab in the metastatic as well as in the adjuvant setting }\end{array}$ & FISH & Yes & [81] \\
\hline Breast & NuvoSelect & $\begin{array}{l}\text { A combination of several pharmacogenomic genesets used primarily to guide } \\
\text { selection of therapy in breast cancer patients. This test also provides the ER and } \\
\text { HER2 mRNA status }\end{array}$ & MA & Yes & {$[113,114]$} \\
\hline Breast & PR & High cellular expression of PR predicts benefit from tamoxifen-based chemotherapy & IHC & Yes & {$[86,109,115]$} \\
\hline Breast & Roche AmpliChip & $\begin{array}{l}\text { Low expression of CYP2D6 predicts resistance to tamoxifen-based chemotherapy in } \\
\text { breast cancer patients }\end{array}$ & MA & Yes & [116] \\
\hline Breast & Rotterdam Signature & $\begin{array}{l}\text { A 76-gene assay used to predict recurrence in ER-positive breast cancer patients } \\
\text { treated with tamoxifen }\end{array}$ & MA & Yes & [117] \\
\hline Breast & PTEN & $\begin{array}{l}\text { PTEN mutation can result in reduced sensitivity of treatment with trastuzumab in } \\
\text { breast cancer patients }\end{array}$ & $\mathrm{IHC}$ & No & [118] \\
\hline CRC & & $\begin{array}{l}\text { EGFR1 gene amplification appears to be a predictive factor for response to anti- } \\
\text { EGFR1 antibody treatment in CRC }\end{array}$ & PCR & Yes & [119] \\
\hline CRC & & $\begin{array}{l}\text { K-ras mutation positivity in stage IV CRC patients predicts considerably less benefit } \\
\text { from EGFR-specific antibody like cetuximab and panitumumab }\end{array}$ & PCR & Yes & [119] \\
\hline CRC & $\mathrm{LOH}$ at $18 \mathrm{q}$ & $\begin{array}{l}\text { Useful in identifying patients with resected stage III colon cancer most likely to benefit } \\
\text { from 5-FU based adjuvant chemotherapy }\end{array}$ & PCR & No & [91] \\
\hline CRC & & $\begin{array}{l}\text { Expression of TP in metastatic colorectal patients is predictive of sensitivity of } \\
\text { treatment to 5-FU and capcetabine based chemotherapy }\end{array}$ & $\begin{array}{l}\text { IHC/qRT- } \\
\text { PCR }\end{array}$ & No & {$[120,121]$} \\
\hline Gastric & & $\begin{array}{l}\text { Expression of Her-2/Neu in gastric cancer is predictive of patient sensitivity towards } \\
\text { treatment with } 5-\mathrm{FU} \text {, doxorubicin, trastuzumab and platinum-based chemotherapy }\end{array}$ & FISH & No & [94] \\
\hline GIST & c-KIT & $\begin{array}{l}\text { GIST patients carrying the mutation on exon } 11 \text { of the c-KIT gene benefit from Imatinib } \\
\text { and Sunitinib treatment, however most patients develop resistance to these over time }\end{array}$ & SA & Yes & [122] \\
\hline GIST & TP & $\begin{array}{l}\text { Predicitve of senstivity of treatment to 5-FU- and capcetabine-based chemotherapy in } \\
\text { gastric cancer patients }\end{array}$ & IHC/PCR & No & [94] \\
\hline Glioblastoma & MGMT & $\begin{array}{l}\text { Methylation of MGMT promoter is predictive of sensitivity of glioblastoma to } \\
\text { temozolomide }\end{array}$ & PCR & No & [123] \\
\hline NSCLC & BRCA1 & $\begin{array}{l}\text { High expression of BRCA1 in NSCLC patients predicts resistance to Cisplatin-based } \\
\text { chemotherapy }\end{array}$ & qRT-PCR & No & [124] \\
\hline NSCLC & EGFR1 & $\begin{array}{l}\text { EGFR1 mutations in patients with NSCLC are predictive for response to either } \\
\text { Gefitinib or Erlotinib treatment }\end{array}$ & $\mathrm{IHC}$ & Yes & [125] \\
\hline NSCLC & ERCC1 & $\begin{array}{l}\text { High expression of ERCC } 1 \text { in NSCLC patients predicts resistance to cisplatin-based } \\
\text { chemotherapy }\end{array}$ & $\mathrm{IHC}$ & No & {$[126,127]$} \\
\hline NSCLC & K-ras & $\begin{array}{l}\text { K-ras mutation positivity in NSCLC patients predicts lack of benefit from adjuvant } \\
\text { chemotherapy in early disease and resistance to treatment with EGFR TKI in } \\
\text { advanced disease }\end{array}$ & SA & Yes & [128] \\
\hline NSCLC & p53 & $\begin{array}{l}\text { High p53 expression in NSCLC patients predicts sensitivity to cisplatin-based } \\
\text { chemotherapy, however TP53 mutation is predicitve of resistance to cisplatin-based } \\
\text { chemotherapy }\end{array}$ & $\mathrm{IHC} / \mathrm{SA}$ & No & {$[101,105]$} \\
\hline NSCLC & RRMI & $\begin{array}{l}\text { High expression of RRM1 in NSCLC patients predict resistance to cisplatin-based } \\
\text { chemotherapy }\end{array}$ & qRT-PCR & No & [129] \\
\hline \multirow[t]{2}{*}{$\mathrm{RCC}$} & CAIX & $\begin{array}{l}\text { Expression of CAIX in renal cell carcinoma is predictive of sensitivity of treatment with } \\
\text { interleukin-2 therapy }\end{array}$ & $\mathrm{IHC}$ & No & [130] \\
\hline & & interleukin-2 therapy & & & \\
\hline
\end{tabular}

Abbreviations: CAIX: Carbonic Anhydrase IX; CRC; Colorectal Tumor; EGFR; Epidermal Growth Factor Receptor; ER: Estrogen Receptor; ERCC1: Excision Repair Cross-Complementation Group 1; FISH: Fluorescent in situ Hybridization; GIST: Gastrointestinal Stromal Tumor; IHC: Immunohistochemistry; LOH: Loss Of Heterozygosity; MGMT: O6-methylguanine-DNA methyltransferase; MA: Microarray; NSCLC: Non-Small Cell Lung Cancer; PCR: Polymerase Chain Reaction; PR: Progesterone Receptor; RRMI: Ribonucleotide Reductase Messenger 1; qRT-PCR: Quantitative Real-Time Polymerase Chain Reaction; RCC: Renal Cell Carcinoma; SA: Sequence Analysis; TK1: Tyrosine Kinase Inhibitor; TP: Thymidine Phosphorylase.

Table 3: Predictive biomarkers for tumor medicine, taken and modified from Ref. [55].

a major breakthrough in genetics. It was an important stride towards the development of far more effective pharmacotherapies with fewer side effects because many diseases have their origins in the human genotype. Often, disorders are not caused by the actual genes. The interpretation of sequencing-based studies of human disease has also been challenging: the thousands of potentially deleterious mutations in the human genome have made it difficult to pinpoint the actual causal gene(s) [132]. Instead they are brought on by mutations, fusions of genetic rearrangements [133], which are found in the human genotype. Many genes control metabolic processes in human cells [134]. Some mutations and other alterations of genes can induce diseases [135].
Others determine whether or not a medication will be effective and tolerated well by the patient [136]. This is why the decoding of the human genome has been such a significant scientific achievement and result further medical advances. If scientists are able to identify the genetic profile of a disease, e.g. a tumor, it can be attacked more purposefully with medications that target the cellular metabolic processes triggered by gene alterations [137]. These disease-specific genetic traits often occur in a very small percentage of patients [138]. The therapies developed to treat such small groups have become known as PM, and sometimes referred to as stratified, tailored or individualized medicine. The most important of genes related to diseases are gathered 
in these references [139-145]. Each of these databases focuses on different aspects of the phenotype-genotype relationship, and due to the nature of the database curation process, they are not complete. Hence, DisGeNET within PM has created [146]. Database of disease-related biomarkers also has created [145].

\section{Opportunities for PM}

Successful applications in cancer therapy: After the human genome's decoding, physicians are already able to treat some diseases successfully using such personalized approaches [147]. Research and development efforts in other fields of medicine have come a long way in recent years, so further therapies are likely to be available soon. The greatest advances in PM so far have been made in chemotherapeutic medications for example, for breast, blood and lung tumor. In no other field of medicine has differentiation progressed as far as in oncology. This development is very much in line with recent findings in the field. For example, today oncologists know that there are at least six different subtypes of lung tumor that can coexist and have different genetic origins [148]. Scientists have also identified the genetic triggers of other tumor types and developed new medications to treat these strains. As this vision gradually becomes reality in day-to-day medical practice, it is changing the work of physicians and the lives of patients. Francis S. Collins, the head of the Human Genome Project, believes that PM could be far more effective than the traditional one-size-fits-all approach that is, the same medicine for everyone. In his view, this insight heralds a "dramatic paradigm shift" in medicine. This paradigm shift paired with further advances in PM would very well change the way physicians diagnose and treat many diseases in particular tumors. Simply an initial blood or tissue test determines if a particular medication is suitable for treating an individual patient. It may help predict how well a patient will tolerate a certain agent and if the regimen is likely to succeed. Such molecular profiling tests mainly screen for organic substances called "biomarkers".

After the human genome's decoding, physicians are already able to treat some diseases successfully using such personalized approaches [147]. Research and development efforts in other fields of medicine have come a long way in recent years, so further therapies are likely to be available soon. The greatest advances in PM so far have been made in chemotherapeutic medications for example, for breast, blood and lung tumor. In no other field of medicine has differentiation progressed as far as in oncology. This development is very much in line with recent findings in the field. For example, today oncologists know that there are at least six different subtypes of lung tumor that can coexist and have different genetic origins [148]. Scientists have also identified the genetic triggers of other tumor types and developed new medications to treat these strains. As this vision gradually becomes reality in day-today medical practice, it is changing the work of physicians and the lives of patients. Francis S. Collins, the head of the Human Genome Project, believes that PM could be far more effective than the traditional onesize-fits-all approach that is, the same medicine for everyone. In his view, this insight heralds a "dramatic paradigm shift" in medicine. This paradigm shift paired with further advances in PM would very well change the way physicians diagnose and treat many diseases in particular tumors. Simply an initial blood or tissue test determines if a particular medication is suitable for treating an individual patient. It may help predict how well a patient will tolerate a certain agent and if the regimen is likely to succeed. Such molecular profiling tests mainly screen for organic substances called "biomarkers".

More effective treatment and fewer side effects: For patients, PM holds the promise of very effective therapies with fewer side effects.
They may be spared the prospects of a treatment with significant side effects but few or no remedial effect. It also increases overall efficiency of healthcare delivery because diagnostic molecular profiling can rule out treatments for patients that will not respond. This is not just to patients' advantage. The healthcare system as a whole benefits because it can contain costs by allocating resources more effectively. The dwindling cost of DNA sequencing is a key development. While genome sequencing cost around US\$500,000 in 2000, it has already dipped to US\$50,000 in 2010 and experts reckon that the price point might soon fall below the US $\$ 1,000$ threshold. The forecast of a group of scientists headed up by the British cancer researcher Ultan McDermott was recently published in the New England Journal of Medicine: "Within a few years, a complete cancer genome sequence will be available for a few hundred dollars or less."

More and more tailored treatments will become available in time. New medications to treat a host of diseases are in the pipeline, and numerous clinical trials are already underway. This provides patients with many unprecedented therapy options. If an agent has yet to be approved for a given indication, treatment within the framework of a clinical trial may well be an alternative. Screening techniques that identify specific biomarkers enable some patients to take part in clinical trials and benefit from new agents.

Numerous patients are unlikely to know much about these new molecular diagnostics or the strategy behind such therapies. One of the new challenges for physicians is to explain all this in consultations with patients. They may have to clear up some misunderstandings about PM. It does not mean that every patient gets medication of their own; instead, the medications are tailored to certain patient groups who exhibit a common genetic biomarker. The size of such patient groups depends on the given genetic biomarker and on the available medications. Some medications are suitable for treating many patients; others are only prescribed for a small group.

Model projects underway standard healthcare practice: Personalized medicine promises to benefit many. Advances in research are not the only factors that determine if and when this promise will be fulfilled for patients. This also depends on how fast healthcare services would be able to adapt their structures and put in place nationwide platforms for screening. The United Kingdom and France, for example, are now setting up comprehensive molecular diagnostics infrastructure. In both countries, the aim is to regularly screen all tumor patients for biomarkers as part of a diagnostic routine, and gather today the information required for the tailored treatments of tomorrow. What the UK and France are planning for tumor patients could soon be standard healthcare practice in other countries and for other medical conditions. We may well see the rise of interdisciplinary networks in which general practitioners, specialists, pathologists, and clinics work together to tailor medication therapies to suit certain patient groups, and in which diagnostics and treatments continue to evolve towards a personalized fit.

Improve quality of life: A molecular diagnostic test that simply requires a blood sample can replace invasive and uncomfortable tissue biopsies. So a multi-gene expression test might help. Two studies suggest that outcomes may be beneficial for patients with bladder tumor who are candidate for rejection. Neoadjuvant chemotherapy is usually applied to muscle-invasive bladder tumor to manage micrometastases and improve prognosis $[149,150]$. A neoadjuvant chemotherapy regimen containing gemcitabine and carboplatin as well as that of methotrexate, vinblastine, doxorubicin and cisplatin, followed by radical cystectomy, have been found to decrease the recurrence 
rate compared to radical cystectomy alone and to improve survival [151-154]. Furthermore, a small subset of patients who respond well to neoadjuvant chemotherapy may have a chance to preserve bladder function and maintain a good quality of life. So these results imply that 'personalized therapy' based on expression levels of a small number of genes may improve the quality of life of a larger proportion of patients with invasive bladder tumor.

Reveal additional or alternative opportunities for medications and medication candidates: Although the prospect of discovering specific multi-targeting medications is attractive, the actual implementation is a complicated endeavor. Medications must be screened against multiple targets at a time and attain specific combinations of target affinities. In the case of Sunitinib, it is still not clear precisely which combinations of its target inhibitions are effective for which tumors [155]. A more rational approach at present would be to determine new targets for existing medicatins. The two foremost reasons for clinical medication attrition are inefficacy and toxicity. From 2008 to $2010,51 \%$ of 87 phase II medications failed clinical trials because of inefficacy, and 19\% failed because of safety issues [156]. From 2007 to $2010,66 \%$ of 83 phase III medications failed due to inefficacy and $21 \%$ because of safety issues [157]. Inadequacy of animal models is a factor in clinical trial failures [158], but two major reasons are disease and patient heterogeneity. Identification and evaluation of a panel of serum biomarkers for predicting response to thalidomide in multiple myeloma patients opened a new window to candidate the medication for multiple melanoma and leprosy [159]. To sum up, finding all the targets of existing medications is essential not only to understand their mode of action and their adverse effects but also to find repositioning opportunities.

\section{Challenges for PM}

Clinically relevant tumor specimens: Based on most studies for molecular discoveries of tumors which were designed in recent years specimens with hindsight obtained from surgical resection methods or diagnostic biopsies. These procedures might not reflect the actual molecular profile of the metastatic tissue. For example in breast tumors some data showing that the PIK3CA mutation status could be different in primary tumor and in metastasis [160]. Furthermore, tumors also have a multipart tissue construction consist of malignant cells, tumor stromal components, host cells and adjacent normal tissues. In other words the effect/s of this heterogeneity and its microenvironment has not yet been fully elucidated. There has been upward credit that tumors are heterogeneous with chromosomal imbalances and separated diverse somatic mutations [161]. Pre-existing or novel genetic alterations would ultimately lead to relapse and cell resistance, through the 'Darwinian' assortment of drug-resistant malignant sub clones. However it is remarkable that despite intra-tumoral heterogeneity during tumor progression, there could be a convergent evolution that leads to the activation of selected pathways by multiple mutations in the same or in different members of the pathway [160].

As previously mentioned, recent progress in the analysis of cellfree DNA fragments [cell-free circulating tumor DNA (ctDNA)] now allows monitoring of tumor genomes by noninvasive means [162]. However, previous studies with plasma DNA from patients with tumor demonstrated highly variable allele frequencies of ctDNA. The comprehensive analysis of tumor genomes is greatly facilitated when plasma DNA has increased amounts of ctDNA found in the blood [163]. This development might permit response monitoring to targeted therapies and modify treatments consequently. Although the analysis of ctDNA is a promising area, and despite all efforts to develop suitable tools for a comprehensive analysis of tumor genomes from plasma DNA, the liquid biopsy is not yet routinely used as a clinical application.

Multiplex technologies: To date most biomarkers discovered and used in clinical applications concern single genetic mutation, epigenetic modification, or gene amplification or translocation $[164,165]$. These biomarkers are not usually adequate to select the optimal targeted therapies as quite a lot of cellular changes, rather than a single amendment, often lead to activation or inactivation of signaling pathways that promote tumor growth and survival [166]. In addition, the use of different targeted therapy regimens might result in the activation of alternative, compensatory mechanisms that continue to promote tumor cell survival [167].

Currently, individual assays of pertinent biomarkers are often carried out before initial treatment in order to classify those patients more susceptible to benefit from a targeted agent [168-170]. However, this approach is associated with some disadvantages mainly including delays in treatment initiation and use of large amounts of precious tissue. Indeed, for those patients whose tumors are negative for tested biomarkers, this approach could potentially delay the initiation of an effective treatment. Performing multiple rounds of assessment of individual biomarkers is not only expensive, but testing might also be limited by the amount of tissue available. These complications will rapidly increase because of the inflation of new 'companion diagnostics' for one single medication currently launched on the market.

Researchers would be able to screen the entire genome, proteome, transcriptome and metabolome for new biomarkers in tumor tissue by development of new technologies. This comprehensive testing could be both tissue sparing and cost effective as many different aberrations are assessed, which could eventually direct patients to several alternative therapies or towards clinical trials with targeted therapies. A clear example of this approach has been assessed in the French clinical trial SAFIR01: a biopsy of one target metastatic lesion has been done in over 400 breast tumor patients with the intention of identifying potential targetable molecular alterations and to treat patients accordingly [171]. This study allowed the identification of a potentially targetable molecular alteration in $70 \%$ of the patients for which a comparative genomic hybridization was feasible.

Models of implementation: There are several controversies about what should be the optimal models to implement PM. In the UK and France, the dominant model is the one where academic hospitals perform the genomic testing for free to citizens [172]. In the USA, biomarker companies propose services that include genomic testing [173]. The optimal model for implementation is not yet defined, and should fit with the overall model of health care system. Thus a standardized, methodological implementation must be applied which has not yet created.

Developing software for treatment decision: One of the major limitations of PM is the fact that each patient is unique regarding its genomic profiling [174]. Indeed, each driver gene occurs with low incidence, and is associated with several other relevant genomic alterations [175]. Medication development in cohorts defined by a genomic alteration is hampered by the low frequency of recurrent genomic alteration [19-21,23-26,176-179]. One possible solution to overcome this limitation is to develop genomic algorithms and software for PM, instead of medication [180]. This kind of trial would test a method for prediction at the individual level, matched with several medications, and no longer a medication in specific population.

Unknown toxicities: With the use of targeted agents against a 
specific molecular alteration from a molecular pathway which role, not only in tumor but also in normal cells, is not completely known, the type of adverse events encountered has changed greatly compared to the adverse events profile of classical chemotherapeutic agents. For some of these class-effect toxicities there is no data or previous experience, as well as a lack of information about its prevalence, its potential reversibility or even its correct management. There is also the potential risk of unknown late effects linked to long-term administration, and not suspected from early-published clinical trials.

As an example, there is the appearance of several skin toxicities associated with the administration of Vemurafenib, including the development of skin squamous cell carcinoma in up to $26 \%$ of the patients [181], interestingly not observed under anti-MEK therapy. For Trastuzumab, its most common and specific adverse effect is the appearance of a potentially reversible cardiotoxicity in terms of decreased left ventricular ejection fraction in around $4 \%$ of the patients, which increases with the use of concomitant or even sequential anthracyclines [182]. Ocular toxicities, such as serous retinal detachment, and retinal vein occlusion have been described with the use of MEK inhibitors but also with other medications interfering with the MAPK pathway like FGFR inhibitors [183]. For some already approved medications, like the anti m-TOR agent Everolimus (Afinitor, Novartis) in renal cell cancer, PNET and lately breast cancer patients, the physiopathology of some toxicities, including non-infectious pneumonitis still remains unknown despite their relatively high frequency (nearby 15\%) [184]. Guidelines for their management and potential biomarkers predictors of its appearance are yet to be determined.

Moreover, the appearance of resistance while the use of targeted therapies with the potential activation of collateral pathways is directing trials towards studies with combined targeted agents for which potential not only additive toxicities are yet to be determined. Regarding immunotherapies, the risk of autoimmune side effects, potentially of grade 3-4, are now clearly recognized, even if those risks are lower with anti-PD1/PDL1 antibodies as compared to those targeting CTLA4 [185]. Nevertheless multiple combinations of immune checkpoints are envisioned and might lead to substantial levels of toxicity.

Inadequate doctor-patient relationship: People debating PM hold understandings that diverge from what PM technology actually can achieve. In other words, PM is not medicine with a special focus on the interests and preferences of the individual patient. For instance, PM does not include any reference to an adequate doctor-patient relationship. Hence, PM as such is not related to the term patient-centered medicine. Moving towards a more patient-centered medicine may be desirable, but cannot be achieved by solely furthering PM technology. To forestall false hopes attached to the concept and accordingly wrong decisions regarding investments, it might be reasonable to adapt terminology. Stratifying medicine, for example, would be a more appropriate term than personalized medicine to describe the developments currently labeled as PM [37].

May be economically viable: Current health economic research shows that personalization of treatment has the potential to improve effectiveness but rising costs. In addition, biomarker testing may lead to more successful R\&D projects. However, the value of so-called tailormade therapies depends to a large extent on the quality of the tailor. Adaptations to both regulatory structures and market structures are necessary to encourage the development of PM. However, there is a widespread doubt about the financial impact of PM. In other words, the economic value of genomics networks as personalized tests for future disease onset or response to specific treatments remains largely unknown. A recent study by Philips et al. reflects this issue and highlights a lag between clinical and economical value assessment of personalized medical tests in current research [154]. The costs associated with PM transition remain unclear, but PM may further widen the economic inequality in health systems between high and low-income countries. This jeopardizes social and political pillars of stability, and highlights the need for a broader translation-oriented focus across the globe [155]. Consequently, pricing and reimbursement of PM need careful consideration and a balanced view on cost-effectiveness and incentives for innovation [156].

\section{Conclusion}

A number of oncogenes-targeting therapies such as the c-KIT inhibitor Imatinib, the anti-HER2 agent Trastuzumab and the ALK inhibitor Crizotinib for the treatment of CML, NSCLC and breast cancer have been successfully developed in the last decades. However, oncogene de-addiction has been facing challenges such as the appearance of resistance resulting from secondary genomic events as well as the genomic instability and the intra-tumor heterogeneity generated by the treatments. Some of these challenges could be overcome by either the administration of several concomitant targeted therapies with the potential inconvenience of costs and toxicity issues or with the implementation of genomic algorithms and software for PM.

Besides, the potential of other systems in tumor biology has emerged during the recent years. Immunotherapy treatment with PD1, PDL1 and anti-CTLA4 therapies in melanoma or the targeting of DNA repair with PARP inhibitors for tumors with HR-deficiency (i.e. BRCA1/2 mutations) clearly stand as promising opportunities with the potential to have an impact on tumor treatment in the very coming years.

The concept of PM is attractive and scientists are convinced that this is the way forward. In this way biomarkers and their discovery would help. However, dissemination of the current status instead of unrealistic promises will be a cornerstone for the acceptance by physicians and patients alike. It would be agreed that the concept of PM is important and an essential field to be developed, there have been few examples where the incorporation of patients' genetic information has led to robust improvements in clinical care. Recent advances in biology, pharmacy and medicine and the development of high throughput technologies have led to the recognition that the vast majority of tumors include a large number of very rare genomic alterations that might be responsible for tumor progression and may therefore stand as very attractive targets for cancer therapy. However, as most of these molecular alterations are present at very low frequency, developing and testing medications is proving challenging and might require large-scale molecular screening programs. The identification of common disease risk variants has undoubtedly revealed new biology and potential new avenues for therapeutic intervention; however, the modest effect sizes of most identified variants has resulted in personalized disease risk calculations with questionable clinical validity and utility. As such, testing for these variants is not common among clinical genetics laboratories and has largely been restricted to direct-to-consumer genetic testing companies [186]. Ongoing genome sequencing studies likely will identify rare variants that may improve the predictability for some diseases, such as tumors, but obviously it is clear that further development of response/risk prediction algorithms is needed. In addition to genomic sequence data, these algorithms could include other forms of clinical, demographic, epigenomic and environmental data, and could potentially utilize more sophisticated network-based personalized modeling approaches. Finally PM would create attractive 
opportunities and challenges for scientists and researchers in superb modern science and technology era who are trying to help patients.

\section{Conflicts of Interest}

The author declares that the manuscript was conducted in the absence of any commercial or financial relationships that could be construed as a potential conflict of interest.

1. A New Biology for the 21 st Century, Ensuring the United States Leads the Coming Biology Revolution (2009) Washington (DC): National Academies Press, USA.

2. Hall JG (2003) Individualized medicine. What the genetic revolution will bring to health care in the 21st century. Can Fam Physician 49: 12-13, 15-17.

3. Ventola CL (2012) The nanomedicine revolution: part 1: emerging concepts. PT 37: $512-525$

4. Ventola CL (2012) The nanomedicine revolution: part 2: current and future clinical applications. PT 37: 582-591.

5. Ventola CL (2012) The nanomedicine revolution: part 3: regulatory and safety challenges. PT 37: 631-639.

6. Halas NJ (2009) The photonic nanomedicine revolution: let the human side of nanotechnology emerge. Nanomedicine (Lond) 4: 369-371.

7. Hood L, Friend SH (2011) Predictive, personalized, preventive, participatory (P4) cancer medicine. Nat Rev Clin Oncol 8: 184-187.

8. Brown PO, Botstein D (1999) Exploring the new world of the genome with DNA microarrays. Nat Genet 21: 33-37.

9. Eckhart AD, Beebe K, Milburn M (2012) Metabolomics as a key integrator for "omic" advancement of personalized medicine and future therapies. Clin Transl Sci 5: 285-288

10. Jordan KW, Nordenstam J, Lauwers GY, Rothenberger DA, Alavi K, et al. (2009) Metabolomic characterization of human rectal adenocarcinoma with intact tissue magnetic resonance spectroscopy. Dis Colon Rectum 52: 520525.

11. Arnedos M, Soria JC, Andre F, Tursz T (2014) Personalized treatments of cancer patients: a reality in daily practice, a costly dream or a shared vision of the future from the oncology community? Cancer Treat Rev 40: 1192-1198.

12. Gerdes MJ, Sood A, Sevinsky C, Pris AD, Zavodszky MI, et al. (2014) Emerging understanding of multiscale tumor heterogeneity. Front Oncol 4: 366.

13. Eifert C, Powers RS (2012) From cancer genomes to oncogenic drivers, tumour dependencies and therapeutic targets. Nat Rev Cancer 12: 572-578.

14. Lopez-Chavez A, Thomas A, Rajan A, Raffeld M, Morrow B, et al. (2015) Molecular profiling and targeted therapy for advanced thoracic malignancies: a biomarker-derived, multiarm, multihistology phase II basket trial. J Clin Oncol 33: $1000-1007$

15. Cardarella S, Johnson BE. The impact of genomic changes on treatment of lung cancer. Am J Respir Crit Care Med 188: 770-775.

16. Black JL, Harrell JC, Leisner TM, Fellmeth MJ, George SD, et al. (2015) CIB1 depletion impairs cell survival and tumor growth in triple-negative breast cancer. Breast Cancer Res Treat 152: 337-346.

17. Brodeur GM (1987) The involvement of oncogenes and suppressor genes in human neoplasia. Adv Pediatr 34: 1-44.

18. Rafii A, Touboul C, Al Thani H, Suhre K, Malek JA (2014) Where cancer genomics should go next: a clinician's perspective. Hum Mol Genet 23: R69-75.

19. Skipper M (2012) Cancer genomics: indicators for drug response from sequencing. Nat Rev Genet 13: 520.

20. Kasarskis A, Yang X, Schadt E (2011) Integrative genomics strategies to elucidate the complexity of drug response. Pharmacogenomics 12: 1695-1715.

21. Wang L, McLeod HL, Weinshilboum RM (2011) Genomics and drug response. N Engl J Med 364: 1144-1153.

22. Marziliano N, Orsini F, Veronese S, Colosimo A, Lauricella C, et al. (2010) Genomics in cardiological clinical practice: from the individual response to drug therapy and monogenic cardiovascular disorders. G Ital Cardiol (Rome) 11: 767-768.
23. Ozawa S (2007) Collaborative causes of individual variation in drug metabolism and pharmacokinetics and drug response: variations discovered from genetics and genomics approaches. Drug Metab Pharmacokinet 22: 141.

24. Zybarth G, Kley N (2006) Investigating the molecular basis of drug action and response: chemocentric genomics and proteomics. Curr Drug Targets 7: 387395.

25. Halapi E, Stefansson K, Hakonarson H (2004) Population genomics of drug response. Am J Pharmacogenomics 4: 73-82.

26. March R (2000) Pharmacogenomics: the genomics of drug response. Yeast 17: 16-21.

27. Csermely P, Korcsmaros T, Kiss HJ, London G, Nussinov R (2013) Structure and dynamics of molecular networks: a novel paradigm of drug discovery: a comprehensive review. Pharmacol Ther 138: 333-408.

28. Roden DM, Pulley JM, Basford MA, Bernard GR, Clayton EW, et al. (2008) Development of a large-scale de-identified DNA biobank to enable personalized medicine. Clin Pharmacol Ther 84: 362-369.

29. Duclos A, Carty MJ (2011) Value of health care delivery. JAMA 306: 267.

30. Bau S, Schracke N, Kranzle M, Wu H, Stahler PF, et al. (2009) Targeted nextgeneration sequencing by specific capture of multiple genomic loci using lowvolume microfluidic DNA arrays. Anal Bioanal Chem 393: 171-175.

31. Shendure J, Ji H (2008) Next-generation DNA sequencing. Nat Biotechnol 26 1135-1145.

32. Mardis ER (2008) Next-generation DNA sequencing methods. Annu Rev Genomics Hum Genet 9: 387-402.

33. Kalia M (2015) Biomarkers for personalized oncology: recent advances and future challenges. Metabolism 64: S16-21.

34. Li SX, Sjolund A, Harris L, Sweasy JB (2010) DNA repair and personalized breast cancer therapy. Environ Mol Mutagen 51: 897-908.

35. Sookoian S, Pirola CJ (2015) Liver enzymes, metabolomics and genome-wide association studies: from systems biology to the personalized medicine. World J Gastroenterol 21: 711-725.

36. Whiteside TL (2010) Inhibiting the inhibitors: evaluating agents targeting cancer immunosuppression. Expert Opin Biol Ther 10: 1019-1035.

37. Schleidgen S, Klingler C, Bertram T, Rogowski WH, Marckmann G (2013) What is personalized medicine: sharpening a vague term based on a systematic literature review. BMC Med Ethics 14: 55.

38. Meyer UA (2004) Pharmacogenetics - five decades of therapeutic lessons from genetic diversity. Nat Rev Genet 5: 669-676.

39. The Academy of Medical Sciences (2013) Realising the potential of stratified medicine. London: AMS.

40. Collins FS, Lander ES, Rogers J, Waterston RH (2004) Finishing the euchromatic sequence of the human genome. Nature 431: 931-945.

41. Gibbs RA, Belmont JW, Boudreau A, Leal SM, Hardenbol P, et al. (2005) A haplotype map of the human genome. Nature 437: 1299-1320.

42. ENCODE Project Consortium (2004) The ENCODE (ENCyclopedia Of DNA Elements) Project. Science 306: 636-640.

43. Birney E, Stamatoyannopoulos JA, Dutta A, Guigo R, Gingeras TR, et al (2007) Identification and analysis of functional elements in $1 \%$ of the human genome by the ENCODE pilot project. Nature 447: 799-816.

44. Kuehn BM (2008) 1000 Genomes Project promises closer look at variation in human genome. JAMA 300: 2715.

45. Siva N (2008) 1000 Genomes project. Nat Biotechnol 26: 256.

46. Kaiser J (2008) DNA sequencing. A plan to capture human diversity in 1000 genomes. Science 319: 395.

47. Ziegler A, Koch A, Krockenberger K, Grosshennig A (2012) Personalized medicine using DNA biomarkers: a review. Hum Genet 131: 1627-1638.

48. Biomarkers Definitions Working Group (2001) Biomarkers and surrogate endpoints: preferred definitions and conceptual framework. Clin Pharmacol Ther 69: 89-95.

4 9. ht t p: / / w w w. fda.gov/downloads/Medical Devices DeviceRegulationandGuidance/GuidanceDocuments/UCM262327.pdf 
50. Nielsen KV, Ejlertsen B, Moller S, Jorgensen JT, Knoop A, et al. (2008) The value of TOP2A gene copy number variation as a biomarker in breast cancer: Update of DBCG trial 89D. Acta Oncol 47: 725-734.

51. Kobayashi E, Ueda Y, Matsuzaki S, Yokoyama T, Kimura T, et al. (2012) Biomarkers for screening, diagnosis, and monitoring of ovarian cancer. Cancer Epidemiol Biomarkers Prev 21: 1902-1912.

52. Kroll W (2008) Biomarkers-predictors, surrogate parameters-a concept definition. Schmitz G ES, Götte D, editors. Biomarker (Eds) Stuttgart: Schattauer.

53. Bock C (2009) Epigenetic biomarker development. Epigenomics 1: 99-110.

54. Nicaise RP, Grootenboer MS, Bruns A, Hurtado M, Palazzo E, et al. (2008) Antibodies to mutated citrullinated vimentin for diagnosing rheumatoid arthritis in anti-CCP-negative patients and for monitoring infliximab therapy. Arthritis Res Ther 10: R142.

55. Mehta S, Shelling A, Muthukaruppan A, Lasham A, Blenkiron C, et al. (2010) Predictive and prognostic molecular markers for cancer medicine. Ther Adv Med Oncol 2: 125-148.

56. Tsunashima R, Naoi Y, Kagara N, Shimoda M, Shimomura A, et al. (2015) Construction of multi-gene classifier for prediction of response to and prognosis after neoadjuvant chemotherapy for estrogen receptor positive breast cancers. Cancer Lett 365: 166-173.

57. Janssens AC, van Duijn CM (2008) Genome-based prediction of common diseases: advances and prospects. Hum Mol Genet 17: R166-173.

58. Sistare FD, Dieterle F, Troth S, Holder DJ, Gerhold D, et al. (2010) Towards consensus practices to qualify safety biomarkers for use in early drug development. Nat Biotechnol 28: 446-454.

59. Gold P, Freedman SO (1965) Demonstration of Tumor-Specific Antigens in Human Colonic Carcinomata by Immunological Tolerance and Absorption Techniques. J Exp Med 121: 439-462.

60. Golub TR, Slonim DK, Tamayo P, Huard C, Gaasenbeek M, et al. (1999) Molecular classification of cancer: class discovery and class prediction by gene expression monitoring. Science 286: 531-537.

61. Barry MJ (1998) PSA screening for prostate cancer: the current controversy-a viewpoint. Patient Outcomes Research Team for Prostatic Diseases. Ann Oncol 9: 1279-1282.

62. Barry MJ (2006) The PSA Conundrum. Arch Intern Med 166: 7-8.

63. Punnen S, Nam RK (2009) Indications and timing for prostate biopsy, diagnosis of early stage prostate cancer and its definitive treatment: a clinical conundrum in the PSA era. Surg Oncol 18: 192-199.

64. Hoffman RM, Couper MP, Zikmund-Fisher BJ, Levin CA, McNaughton-Collins $M$, et al. (2009) Prostate cancer screening decisions: results from the National Survey of Medical Decisions (DECISIONS study). Arch Intern Med 169: 16111618.

65. Miyake H, Eto H, Arakawa S, Kamidono S, Hara I (2002) Over expression of CD44V8-10 in urinary exfoliated cells as an independent prognostic predictor in patients with urothelial cancer. J Urol 167: 1282-1287.

66. Liukkonen T, Lipponen P, Raitanen M, Kaasinen E, Ala-Opas M, et al. (2000) Evaluation of p21WAF1/CIP1 and cyclin D1 expression in the progression of superficial bladder cancer. Finbladder Group. Urol Res 28: 285-292.

67. Richter J, Wagner U, Kononen J, Fijan A, Bruderer J, et al. (2000) Highthroughput tissue microarray analysis of cyclin $E$ gene amplification and overexpression in urinary bladder cancer. Am J Pathol 157: 787-794.

68. Bringuier PP, Umbas R, Schaafsma HE, Karthaus HF, Debruyne FM, et al. (1993) Decreased E-cadherin immunoreactivity correlates with poor survival in patients with bladder tumors. Cancer Res 53: 3241-3245.

69. Nguyen PL, Swanson PE, Jaszcz W, Aeppli DM, Zhang G, et al. (1994) Expression of epidermal growth factor receptor in invasive transitional cell carcinoma of the urinary bladder. A multivariate survival analysis. Am J Clin Pathol 101: 166-176.

70. Lipponen P, Eskelinen M, Syrjanen S, Tervahauta A, Syrjanen K (1991) Use of immunohistochemically demonstrated c-erb B-2 oncoprotein expression as a prognostic factor in transitional cell carcinoma of the urinary bladder. Eur Urol 20: $238-242$

71. Gerdes J, Lemke H, Baisch H, Wacker HH, Schwab U, et al. (1984) Cell cycle analysis of a cell proliferation-associated human nuclear antigen defined by the monoclonal antibody Ki-67. J Immunol 133: 1710-1715.

72. Xu K, Hou S, Du Z (2002) Prognostic value of matrix metalloproteinase-2 and tissue inhibitor of metalloproteinase-2 in bladder carcinoma. Chin Med J (Engl) 115: 743-745.

73. Logothetis CJ, Xu HJ, Ro JY, Hu SX, Sahin A, et al. (1992) Altered expression of retinoblastoma protein and known prognostic variables in locally advanced bladder cancer. J Natl Cancer Inst 84: 1256-1261.

74. Stein JP, Ginsberg DA, Grossfeld GD, Chatterjee SJ, Esrig D, et al. (1998) Effect of p21WAF1/CIP1 expression on tumor progression in bladder cancer. $J$ Natl Cancer Inst 90: 1072-1079.

75. Schmitz-Drager BJ, Goebell PJ, Ebert T, Fradet $Y$ (2000) p53 immunohistochemistry as a prognostic marker in bladder cancer. Playground for urology scientists? Eur Urol 38: 691-700.

76. Dowsett M, Smith IE, Ebbs SR, Dixon JM, Skene A, et al. (2007) Prognostic value of Ki67 expression after short-term presurgical endocrine therapy for primary breast cancer. J Natl Cancer Inst 99: 167-170.

77. James CR, Quinn JE, Mullan PB, Johnston PG, Harkin DP (2007) BRCA1, a potential predictive biomarker in the treatment of breast cancer. Oncologist 12: 142-150.

78. Cristofanilli M, Budd GT, Ellis MJ, Stopeck A, Matera J, et al. (2004) Circulating tumor cells, disease progression, and survival in metastatic breast cancer. N Engl J Med 351: 781-791.

79. (1998) Tamoxifen for early breast cancer: an overview of the randomised trials. Early Breast Cancer Trialists' Collaborative Group. Lancet 351: 1451-1467.

80. Davis LM, Harris C, Tang L, Doherty P, Hraber P, et al. (2007) Amplification patterns of three genomic regions predict distant recurrence in breast carcinoma. J Mol Diagn 9: 327-336.

81. Mass RD, Press MF, Anderson S, Cobleigh MA, Vogel CL, et al. (2005) Evaluation of clinical outcomes according to HER2 detection by fluorescence in situ hybridization in women with metastatic breast cancer treated with trastuzumab. Clin Breast Cancer 6: 240-246.

82. van 't Veer LJ, Dai H, van de Vijver MJ, He YD, Hart AA, et al. (2002) Gene expression profiling predicts clinical outcome of breast cancer. Nature 415: 530-536.

83. Ring BZ, Seitz RS, Beck R, Shasteen WJ, Tarr SM, et al. (2006) Novel prognostic immunohistochemical biomarker panel for estrogen receptorpositive breast cancer. J Clin Oncol 24: 3039-3047.

84. Goldstein LJ, Gray R, Badve S, Childs BH, Yoshizawa C, et al. (2008) Prognostic utility of the 21-gene assay in hormone receptor-positive operable breast cancer compared with classical clinicopathologic features. J Clin Oncol 26: 4063-4071.

85. Paik S, Shak S, Tang G, Kim C, Baker J, et al. (2004) A multigene assay to predict recurrence of tamoxifen-treated, node-negative breast cancer. $\mathrm{N}$ Engl J Med 351: 2817-2826

86. Dowsett M, Houghton J, Iden C, Salter J, Farndon J, et al. (2006) Benefit from adjuvant tamoxifen therapy in primary breast cancer patients according oestrogen receptor, progesterone receptor, EGF receptor and HER2 status. Ann Oncol 17: 818-826.

87. Cohen SJ, Punt CJ, lannotti N, Saidman BH, Sabbath KD, et al. (2009) Prognostic significance of circulating tumor cells in patients with metastatic colorectal cancer. Ann Oncol 20: 1223-1229.

88. Wolmark N, Fisher B, Wieand HS, Henry RS, Lerner H, et al. (1984) The prognostic significance of preoperative carcinoembryonic antigen levels in colorectal cancer. Results from NSABP (National Surgical Adjuvant Breast and Bowel Project) clinical trials. Ann Surg 199: 375-382.

89. Wanebo HJ, Rao B, Pinsky CM, Hoffman RG, Stearns M, et al. (1978) Preoperative carcinoembryonic antigen level as a prognostic indicator in colorectal cancer. N Engl J Med 299: 448-451.

90. Glas AM, Roepman P, Salazar R, Capella G, Moreno V, et al. (2009) Development and validation of a robust prognostic and predictive signature for colorectal cancer (CRC) patients. J Clin Oncol 27: 4036-4036.

91. Watanabe T, Wu TT, Catalano PJ, Ueki T, Satriano R, et al. (2001) Molecular predictors of survival after adjuvant chemotherapy for colon cancer. $\mathrm{N}$ Engl J Med 344: 1196-1206. 
92. Kim GP, Colangelo LH, Wieand HS, Paik S, Kirsch IR, et al. (2007) Prognostic and predictive roles of high-degree microsatellite instability in colon cancer: a National Cancer Institute-National Surgical Adjuvant Breast and Bowel Project Collaborative Study. J Clin Oncol 25: 767-772.

93. Singer S, Rubin BP, Lux ML, Chen CJ, Demetri GD, et al. (2002) Prognostic value of KIT mutation type, mitotic activity, and histologic subtype in gastrointestinal stromal tumors. J Clin Oncol 20: 3898-3905.

94. Scartozzi M, Bittoni A, Pistelli M, Galizia E, Berardi R, et al. (2009) Toward molecularly selected chemotherapy for advanced gastric cancer: state of the art and future perspectives. Cancer Treat Rev 35: 451-462.

95. Nezos A, Lembessis P, Sourla A, Pissimissis N, Gogas H, et al. (2009) Molecular markers detecting circulating melanoma cells by reverse transcription polymerase chain reaction: methodological pitfalls and clinical relevance. Clin Chem Lab Med 47: 1-11.

96. Reschke M, Mihic-Probst D, van der Horst EH, Knyazev P, Wild PJ, et al. (2008) HER3 is a determinant for poor prognosis in melanoma. Clin Cancer Res 14: 5188-5197.

97. Wang Y, Dai DL, Martinka M, Li G (2007) Prognostic significance of nuclear ING3 expression in human cutaneous melanoma. Clin Cancer Res 13: 4111 4116.

98. Li J, Martinka M, Li G (2008) Role of ING4 in human melanoma cell migration, invasion and patient survival. Carcinogenesis 29: 1373-1379.

99. Rangel J, Torabian S, Shaikh L, Nosrati M, Baehner FL, et al. (2006) Prognostic significance of nuclear receptor coactivator-3 overexpression in primary cutaneous melanoma. J Clin Oncol 24: 4565-4569.

100. Seve P, Lai R, Ding K, Winton T, Butts C, et al. (2007) Class III beta-tubulin expression and benefit from adjuvant cisplatin/vinorelbine chemotherapy in operable non-small cell lung cancer: analysis of NCIC JBR.10. Clin Cancer Res 13: 994-999.

101. Winton T, Livingston R, Johnson D, Rigas J, Johnston M, et al. (2005) Vinorelbine plus cisplatin vs. observation in resected non-small-cell lung cancer. N Engl J Med 352: 2589-2597.

102. Rosell R, Skrzypski M, Jassem E, Taron M, Bartolucci R, et al. (2007) BRCA1: a novel prognostic factor in resected non-small-cell lung cancer. PLoS One 2: e1129.

103. Coate LE, John T, Tsao MS, Shepherd FA (2009) Molecular predictive and prognostic markers in non-small-cell lung cancer. Lancet Oncol 10: 10011010.

104. Zhu W, Qin W, Atasoy U, Sauter ER (2009) Circulating microRNAs in breast cancer and healthy subjects. BMC Res Notes 2: 89.

105. Tsao MS, Aviel-Ronen S, Ding K, Lau D, Liu N, et al. (2007) Prognostic and predictive importance of p53 and RAS for adjuvant chemotherapy in non small-cell lung cancer. J Clin Oncol 25: 5240-5247.

106. Zheng Z, Chen T, Li X, Haura E, Sharma A, et al. (2007) DNA synthesis and repair genes RRM1 and ERCC1 in lung cancer. N Engl J Med 356: 800-808.

107. Ferrone CR, Finkelstein DM, Thayer SP, Muzikansky A, Fernandez-delCastillo C, et al. (2006) Perioperative CA19-9 levels can predict stage and survival in patients with resectable pancreatic adenocarcinoma. J Clin Oncol 24: 2897 2902.

108. Bui MH, Seligson D, Han KR, Pantuck AJ, Dorey FJ, et al. (2003) Carbonic anhydrase IX is an independent predictor of survival in advanced renal clear cell carcinoma: implications for prognosis and therapy. Clin Cancer Res 9: 802-811.

109. Oldenhuis CN, Oosting SF, Gietema JA, de Vries EG (2008) Prognostic versus predictive value of biomarkers in oncology. Eur J Cancer 44: 946-953.

110. Kuremsky JG, Tepper JE, McLeod HL (2009) Biomarkers for response to neoadjuvant chemoradiation for rectal cancer. Int J Radiat Oncol Biol Phys 74: 673-688.

111. Ettl T, Schwarz S, Kleinsasser N, Hartmann A, Reichert TE, et al. (2008) Overexpression of EGFR and absence of C-KIT expression correlate with poor prognosis in salivary gland carcinomas. Histopathology 53: 567-577.

112. Paik S, Tang G, Shak S, Kim C, Baker J, et al. (2006) Gene expression and benefit of chemotherapy in women with node-negative, estrogen receptorpositive breast cancer. J Clin Oncol 24: 3726-3734.
113. Rouzier R, Pusztai L, Delaloge S, Gonzalez-Angulo AM, Andre F, et al. (2005) Nomograms to predict pathologic complete response and metastasis-free survival after preoperative chemotherapy for breast cancer. J Clin Oncol 23 : 8331-8339.

114. Ayers M, Symmans WF, Stec J, Damokosh Al, Clark E, et al. (2004) Gene expression profiles predict complete pathologic response to neoadjuvant paclitaxel and fluorouracil, doxorubicin, and cyclophosphamide chemotherapy in breast cancer. J Clin Oncol 22: 2284-2293.

115. Elledge RM, Green S, Pugh R, Allred DC, Clark GM, et al. (2000) Estrogen receptor $(\mathrm{ER})$ and progesterone receptor $(\mathrm{PgR})$, by ligand-binding assay compared with $\mathrm{ER}, \mathrm{PgR}$ and $\mathrm{pS} 2$, by immuno-histochemistry in predicting response to tamoxifen in metastatic breast cancer: a Southwest Oncology Group Study. Int J Cancer 89: 111-117.

116. Hoskins JM, Carey LA, McLeod HL (2009) CYP2D6 and tamoxifen: DNA matters in breast cancer. Nat Rev Cancer 9: 576-586.

117. Wang Y, Klijn JG, Zhang Y, Sieuwerts AM, Look MP, et al. (2005) Geneexpression profiles to predict distant metastasis of lymph-node-negative primary breast cancer. Lancet 365: 671-679.

118. Nagata Y, Lan KH, Zhou X, Tan M, Esteva FJ, et al. (2004) PTEN activation contributes to tumor inhibition by trastuzumab, and loss of PTEN predicts trastuzumab resistance in patients. Cancer Cell 6: 117-127.

119. Amado RG, Wolf M, Peeters M, Van Cutsem E, Siena S, et al. (2008) Wildtype KRAS is required for panitumumab efficacy in patients with metastatic colorectal cancer. J Clin Oncol 26: 1626-1634.

120. Meropol NJ, Gold PJ, Diasio RB, Andria M, Dhami M, et al. (2006) Thymidine phosphorylase expression is associated with response to capecitabine plus irinotecan in patients with metastatic colorectal cancer. J Clin Oncol 24: 40694077 .

121. Metzger R, Danenberg $K$, Leichman CG, Salonga D, Schwartz EL, et al. (1998) High basal level gene expression of thymidine phosphorylase (plateletderived endothelial cell growth factor) in colorectal tumors is associated with nonresponse to 5-fluorouracil. Clin Cancer Res 4: 2371-2376.

122. Dematteo RP, Ballman KV, Antonescu CR, Maki RG, Pisters PW, et al. (2009) Adjuvant imatinib mesylate after resection of localised, primary gastrointestinal stromal tumour: a randomised, double-blind, placebo-controlled trial. Lancet 373: 1097-1104.

123. Dunn J, Baborie A, Alam F, Joyce K, Moxham M, et al. (2009) Extent of MGMT promoter methylation correlates with outcome in glioblastomas given temozolomide and radiotherapy. $\mathrm{Br} \mathrm{J}$ Cancer 101: 124-131.

124. Cobo MS, Massuti B, Moran T, Chaib L, Pérez-Roca U, et al. (2008) Spanish Customized Adjuvant Trial (SCAT) based on BRCA1 mRNA levels. Proc Am Soc Clin Oncol 26.

125. Sequist LV, Bell DW, Lynch TJ, Haber DA (2007) Molecular predictors of response to epidermal growth factor receptor antagonists in non-small-cell lung cancer. J Clin Oncol 25: 587-595.

126. Olaussen KA, Dunant A, Fouret P, Brambilla E, Andre F, et al. (2006) DNA repair by ERCC1 in non-small-cell lung cancer and cisplatin-based adjuvant chemotherapy. N Engl J Med 355: 983-991.

127. Arriagada R, Bergman B, Dunant A, Le Chevalier T, Pignon JP, et al. (2004) Cisplatin-based adjuvant chemotherapy in patients with completely resected non-small-cell lung cancer. N Engl J Med 350: 351-360.

128. Mascaux C, lannino N, Martin B, Paesmans M, Berghmans T, et al. (2005) The role of RAS oncogene in survival of patients with lung cancer: a systematic review of the literature with meta-analysis. $\mathrm{Br} \mathrm{J}$ Cancer 92: 131-139.

129. Rosell R, Danenberg KD, Alberola V, Bepler G, Sanchez JJ, et al. (2004) Ribonucleotide reductase messenger RNA expression and survival in gemcitabine/cisplatin-treated advanced non-small cell lung cancer patients. Clin Cancer Res 10: 1318-1325.

130. Tunuguntla HS, Jorda M (2008) Diagnostic and prognostic molecular markers in renal cell carcinoma. J Urol 179: 2096-2102.

131. Buyse M, Michiels S, Sargent DJ, Grothey A, Matheson A, et al. (2011) Integrating biomarkers in clinical trials. Expert Rev Mol Diagn 11: 171-182.

132. Cooper GM, Shendure J (2011) Needles in stacks of needles: finding diseasecausal variants in a wealth of genomic data. Nat Rev Genet 12: 628-640. 
133. Mertens F, Johansson B, Fioretos T, Mitelman F (2015) The emerging complexity of gene fusions in cancer. Nat Rev Cancer 15: 371-381.

134. Pisabarro AG, Perez G, Lavin JL, Ramirez L (2008) Genetic networks for the functional study of genomes. Brief Funct Genomic Proteomic 7: 249-263.

135. Zucman-Rossi J, Villanueva A, Nault JC, Llovet JM (2015) The genetic landscape and biomarkers of hepatocellular carcinoma. Gastroenterology.

136. Goswami CP, Cheng L, Alexander PS, Singal A, Li L (2015) A New Drug Combinatory Effect Prediction Algorithm on the Cancer Cell Based on Gene Expression and Dose-Response Curve. CPT Pharmacometrics Syst Pharmacol 4: e9.

137. Hattori H, Janky R, Nietfeld W, Aerts S, Madan Babu M,et al. (2014) p53 shapes genome-wide and cell type-specific changes in microRNA expression during the human DNA damage response. Cell Cycle 13: 2572-2586.

138. Rivenbark AG, O'Connor SM, Coleman WB (2013) Molecular and cellular heterogeneity in breast cancer: challenges for personalized medicine. Am J Pathol 183: 1113-1124.

139. Wang $H$, Sun $Q$, Zhao W, Qi L, Gu Y, et al. (2015) Individual-level analysis of differential expression of genes and pathways for personalized medicine. Bioinformatics 31: 62-68.

140. Hirschhorn JN, Daly MJ (2005) Genome-wide association studies for common diseases and complex traits. Nat Rev Genet 6: 95-108.

141. Davis AP, Murphy CG, Johnson R, Lay JM, Lennon-Hopkins K, et al. (2013) The Comparative Toxicogenomics Database: update 2013. Nucleic Acids Res 41: D1104-D1114.

142. Hamosh A, Scott AF, Amberger JS, Bocchini CA, McKusick VA (2005) Online Mendelian Inheritance in Man (OMIM), a knowledgebase of human genes and genetic disorders. Nucleic Acids Res 33: D514-D517.

143. Hamosh A, Scott AF, Amberger J, Bocchini C, Valle D, et al. (2002) Online Mendelian Inheritance in Man (OMIM), a knowledgebase of human genes and genetic disorders. Nucleic Acids Res 30: 52-55.

144. Becker KG, Barnes KC, Bright TJ, Wang SA (2004) The genetic association database. Nat Genet 36: 431-432.

145. Bravo A, Cases M, Queralt-Rosinach N, Sanz F, Furlong LI (2014) A knowledge-driven approach to extract disease-related biomarkers from the literature. Biomed Res Int 2014: 253128.

146. Pinero J, Queralt-Rosinach N, Bravo A, Deu-Pons J, Bauer-Mehren A, et al. (2015) DisGeNET: a discovery platform for the dynamical exploration of human diseases and their genes. Database (Oxford) 2015: bav028.

147. Venter JC, Adams MD, Myers EW, Li PW, Mural RJ, et al. (2001) The sequence of the human genome. Science 291: 1304-1351.

148. The Clinical Lung Cancer Genome Project, Network Genomic Medicine (2013) A genomics-based classification of human lung tumors. Sci Transl Med 5: 209 ra153.

149. Fagg SL, Dawson-Edwards P, Hughes MA, Latief TN, Rolfe EB, et al. (1984) Cis-diamminedichloroplatinum (DDP) as initial treatment of invasive bladder cancer. Br J Urol 56: 296-300.

150. Raghavan D, Pearson B, Coorey G, Woods W, Arnold D, et al. (1984) Intravenous cis-platinum for invasive bladder cancer. Safety and feasibility of a new approach. Med J Aust 140: 276-278.

151. Advanced Bladder Cancer (ABC) Meta-analysis Collaboration (2005) Neoadjuvant chemotherapy in invasive bladder cancer: update of a systematic review and meta-analysis of individual patient data advanced bladder cancer (ABC) meta-analysis collaboration. Eur Urol 48: 202-205.

152. Grossman HB, Natale RB, Tangen CM, Speights VO, Vogelzang NJ, et al. (2003) Neoadjuvant chemotherapy plus cystectomy compared with cystectomy alone for locally advanced bladder cancer. N Engl J Med 349: 859-866.

153. von der Maase H, Sengelov L, Roberts JT, Ricci S, Dogliotti L, et al. (2005) Long-term survival results of a randomized trial comparing gemcitabine plus cisplatin, with methotrexate, vinblastine, doxorubicin, plus cisplatin in patients with bladder cancer. J Clin Oncol 23: 4602-4608.

154. Cam K, Yildirim A, Ozveri H, Turkeri L, Akdas A (2002) The efficacy of neoadjuvant chemotherapy in invasive bladder cancer. Int Urol Nephrol 33: 49-52.
155. Petrelli A, Giordano S (2008) From single- to multi-target drugs in cance therapy: when aspecificity becomes an advantage. Curr Med Chem 15: $422-$ 432.

156. Arrowsmith J (2011) Trial watch: Phase II failures: 2008-2010. Nat Rev Drug Discov 10: 328-329.

157. Arrowsmith J (2011) Trial watch: phase III and submission failures: 2007-2010. Nat Rev Drug Discov 10: 87.

158. (2006) The bitterest pill. Nature 444: 532-533.

159. Vargesson N (2015) Thalidomide-induced teratogenesis: History and mechanisms. Birth Defects Res C Embryo Today 105: 140-156.

160. Dupont Jensen J, Laenkholm AV, Knoop A, Ewertz M, Bandaru R, et al. (2011) PIK3CA mutations may be discordant between primary and corresponding metastatic disease in breast cancer. Clin Cancer Res 17: 667-677.

161. Ginsburg GS, Willard HF (2009) Genomic and personalized medicine: foundations and applications. Transl Res 154: 277-287.

162. Heitzer E, Ulz P, Geigl JB (2015) Circulating tumor DNA as a liquid biopsy for cancer. Clin Chem 61: 112-123.

163. Diehl F, Schmidt K, Choti MA, Romans K, Goodman S, et al. (2008) Circulating mutant DNA to assess tumor dynamics. Nat Med 14: 985-990.

164. Werner M, Ballo MS, Gallagher JV (1993) Comparative clinical evaluation of biochemical and genomic tumor markers. Clin Chim Acta 217: 39-55.

165. (2008) Biomarkers-at-a-crossroads. Abstracts of the National Cancer Institute Early Detection Research Network 5th Scientific Workshop. March 17-19, 2008. Bethesda, Maryland, USA. Cancer Biomark 4: 121-192.

166. Siena S, Sartore-Bianchi A, Di Nicolantonio F, Balfour J, Bardelli A (2009) Biomarkers predicting clinical outcome of epidermal growth factor receptortargeted therapy in metastatic colorectal cancer. J Natl Cancer Inst 101: 13081324.

167. Pastorino U, Bellomi M, Landoni C, De Fiori E, Arnaldi P, et al. (2003) Early lung-cancer detection with spiral CT and positron emission tomography in heavy smokers: 2-year results. Lancet 362: 593-597.

168. Evaluation of Genomic Applications in Practice and Prevention (EGAPP) Working Group (2014) Recommendations from the EGAPP Working Group: does PCA3 testing for the diagnosis and management of prostate cancer improve patient health outcomes? Genet Med 16: 338-346.

169. (2013) Recommendations from the EGAPP Working Group: does genomic profiling to assess type 2 diabetes risk improve health outcomes? Genet Med 15: 612-617.

170. (2013) Recommendations from the EGAPP Working Group: can testing of tumor tissue for mutations in EGFR pathway downstream effector genes in patients with metastatic colorectal cancer improve health outcomes by guiding decisions regarding anti-EGFR therapy? Genet Med 15: 517-527.

171. Andre F, Bachelot T, Commo F, Campone M, Arnedos M, et al. (2014) Comparative genomic hybridisation array and DNA sequencing to direct treatment of metastatic breast cancer: a multicentre, prospective trial (SAFIR01/UNICANCER). Lancet Oncol 15: 267-274.

172. Nowak F, Soria JC, Calvo F (2012) Tumour molecular profiling for deciding therapy-the French initiative. Nat Rev Clin Oncol 9: 479-486.

173. Frampton GM, Fichtenholtz A, Otto GA, Wang K, Downing SR, et al. (2013) Development and validation of a clinical cancer genomic profiling test based on massively parallel DNA sequencing. Nat Biotechnol 31: 1023-1031.

174. Bombard Y, Rozmovits L, Trudeau ME, Leighl NB, Deal K,et al. (2014) Patients' perceptions of gene expression profiling in breast cancer treatment decisions. Curr Oncol 21: e203-e211.

175. Bozic I, Antal T, Ohtsuki H, Carter H, Kim D, et al. (2010) Accumulation of driver and passenger mutations during tumor progression. Proc Natl Acad Sci U S A 107: 18545-18550.

176. Weinshilboum R (2003) Inheritance and drug response. N Engl J Med 348 : 529-537.

177. Sattiraju S, Reyes S, Kane GC, Terzic A (2008) K(ATP) channel pharmacogenomics: from bench to bedside. Clin Pharmacol Ther 83: 354-357.

178. Weinshilboum R, Wang L (2004) Pharmacogenomics: bench to bedside. Nat Rev Drug Discov 3: 739-748. 
179. Weinshilboum R, Wang L (2005) Pharmacogenomics: Bench to bedside. Discov Med 5: 30-36.

180. Bielinski SJ, Olson JE, Pathak J, Weinshilboum RM, Wang L, et al. (2014) Preemptive genotyping for personalized medicine: design of the right drug, right dose, right time-using genomic data to individualize treatment protocol. Mayo Clin Proc 89: 25-33.

181. Boussemart L, Routier E, Mateus C, Opletalova K, Sebille G, et al. (2013) Prospective study of cutaneous side-effects associated with the BRAF inhibitor vemurafenib: a study of 42 patients. Ann Oncol 24: 1691-1697.

182. Romond EH, Jeong JH, Rastogi P, Swain SM, Geyer CE Jr., et al. (2012) Seven-year follow-up assessment of cardiac function in NSABP B-31, a randomized trial comparing doxorubicin and cyclophosphamide followed by paclitaxel (ACP) with ACP plus trastuzumab as adjuvant therapy for patients with node-positive, human epidermal growth factor receptor 2-positive breast cancer. J Clin Oncol 30: 3792-3799.
183. van der Noll R, Leijen S, Neuteboom GH, Beijnen JH, Schellens JH (2013) Effect of inhibition of the FGFR-MAPK signaling pathway on the development of ocular toxicities. Cancer Treat Rev 39: 664-672.

184. Baselga J, Campone M, Piccart M, Burris HA 3rd, Rugo HS, et al. (2012) Everolimus in postmenopausal hormone-receptor-positive advanced breast cancer. N Engl J Med 366: 520-529.

185. Rolfo C, Sortino G, Smits E, Passiglia F, Bronte G, et al. (2014) Immunotherapy: is a minor god yet in the pantheon of treatments for lung cancer? Expert Rev Anticancer Ther 14: 1173-1187.

186. Abul-Husn NS, Owusu Obeng A, Sanderson SC, Gottesman O, Scott SA (2014) Implementation and utilization of genetic testing in personalized medicine. Pharmgenomics Pers Med 7: 227-240. 